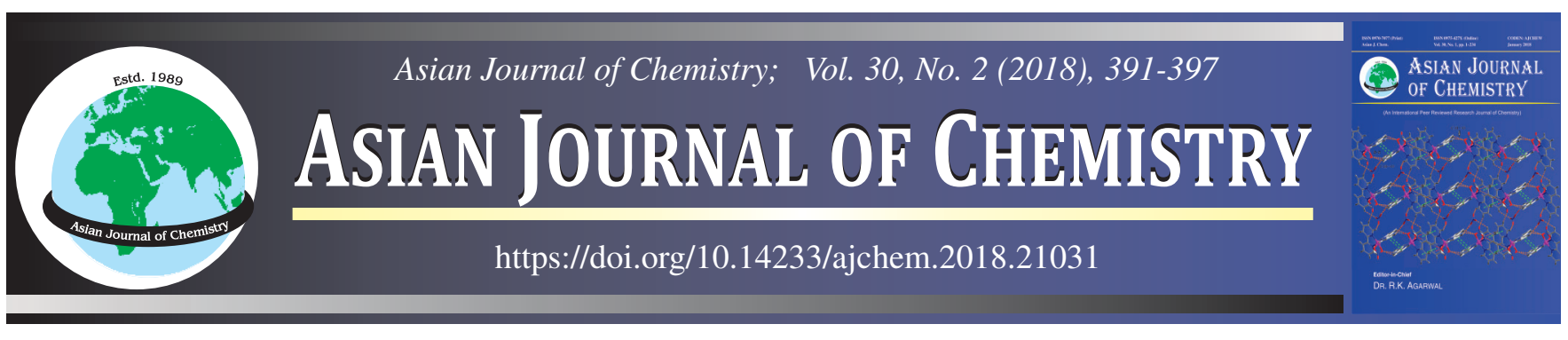

\title{
Olive Mill Wastewater Treatment Using Simple Raw and Purified Jordanian Bentonite Based Low-Cost Method
}

\author{
Khansaa Al-Essa
}

Department of Chemistry, University of Jerash, Jerash 26150, Jordan

Corresponding author: Tel: +962 798619151; E-mail: k.essa@jpu.edu.jo; khansaa.essa@gmail.com

\begin{abstract}
Olive mill wastewater, a by-product of the olive oil industry, is an environmental problem in Jordan and Mediterranean basin countries, due to its high pollutants load, which resist biological degradation. The aim of this study is to achieve a complete physico-chemical characterization of the samples of the olive mill wastewater collected from a village in Jerash city. Furthermore, investigating a low cost method to treat the olive mill wastewater, depending on natural Jordanian clay; raw bentonite as adsorbent. On the other hand, we tried to enhance the adsorption capacity of raw bentonite and its other characteristics by simple and cheap purification method (purified bentonite). A successive column technique was performed to remove $\mathrm{Zn}, \mathrm{Fe}$ and $\mathrm{Mn}$ ions from the olive mill wastewater, the \% uptake for all metal exceeded the $99 \%$. Moreover, a comparison between raw bentonite and purified bentonite as adsorbent was made using batch technique. We found that the purified bentonite has a higher adsorption capacity and the concentrations of potassium, total chlorine, $\mathrm{PO}_{4}{ }^{3-}$ and $\mathrm{NO}_{3}{ }^{-}$ were decreased. Operating temperature is considerably affected the efficiency of phenolic compounds removal, the experiment was carried out at $298,303,313$ and $323 \mathrm{~K}$. it can be noticed that \% removal increased with the increase of temperature.
\end{abstract}

Keywords: Raw bentonite, Purified bentonite, Olive mill wastewater, Adsorption.

\section{INTRODUCTION}

The world is facing challenges regarding rising demands for clean water, since available supplies of freshwater are continually decreasing, because of the increasing size of populations. Water scarcity especially affects agricultural irrigation, which represents the largest demand for fresh water worldwide, that is, more than $70 \%$ of total water consumption [1]. However, the possibility of using regenerated wastewater for irrigation purposes would solve this problem and bring about positive environmental and economic impacts.

In this regard, the olive oil industry, which is currently one of the main agro-industrial activities in the Mediterranean basin countries and particularly in Jordan, generates one of the most highly polluted effluents known nowadays as olive mill wastewater (OMWW) [2].

The amount of this effluent and its physico-chemical properties are influenced by several factors such as the variety of the olives, the meteorological conditions and the extraction process [3]. This effluent is an acidic, black colour with high chemical oxygen demand (COD) and high concentrations of organic matter, such as phenolic compounds [4]. In addition, inorganic compounds, such as chloride, sulfate, potassium, calcium, iron, magnesium, sodium, copper and traces of other elements are usually present in olive mill wastewater [5].

For this reason, olive mill wastewater represents a serious environmental problem, which causes severe deterioration, such as colouring of natural waters, serious risks to aquatic life, pollution in surface and ground waters, changes in soil quality and odor irritation [6,7].

In order to overcome these problems, the treatment of olive mill wastewater is an essential need for environmental protection and it has been studied by several methods, such as physico-chemical treatment [8], electrocoagulation [9], composting [10], biological treatments and enzymatic treatment [11], bioreactors [12] and membranes filtration [13]. However, an environmentally safe and cost-effective solution to olive mill wastewater treatment has not yet been found [14]. Most studies have been devoted to building efficient treatment technologies for olive mill wastewater and they are not economically feasible, due to the short olive oil season [15].

Wastewater is treated using several techniques to remove heavy metal ions (HMIS) and other organic pollutants e.g., chemical precipitation, conventional coagulation, reverse osmosis, ion-exchange, electrodialysis and electrolysis [16]. Most of these techniques are complicated, time consuming 
and expensive [17], which largely prevents their use in developing countries, such as Jordan, which is severely affected by water pollution. However, adsorption is a less expensive, more effective, simplicity of design and environmentally safer technique that removes both organic and inorganic pollutants [18]. It is thus highly attractive for water treatment, especially in developing countries. Nowadays, different natural adsorbents have been used in terms of reactivity, performance and lowcost, to remove various metal ions and phenolic compounds; zeolites [19,20], bentonite [21,22], montmorillonite [23,24], smectite $[25,26]$ and activated carbons $[27,28]$, respectively.

Bentonite is rich clay mineral, commonly available and it exists as discrete deposits. It consists of layers made up of an octahedral alumina sheet sandwiched between two tetrahedral silica sheets [29]. The wide use of bentonite as a low cost adsorbent may be attributed to its high surface area, high chemical, thermal and mechanical stability and to a variety of surface and structural properties [30]. Furthermore, bentonite (after some modification) has exhibited greater stability than other minerals studied in relation to adsorption/desorption processes, maintaining $73 \%$ of its initial adsorption capacity after 14 successive regeneration cycles [31]. The main objective of this study is to investigate a suitable and feasible method for olive mill wastewater treatment.

\section{EXPERIMENTAL}

Adsorbent preparation: Bentonite samples were collected from the airport region, (AlAzraq) in Jordan. These samples were crushed to particle size $>250 \mu \mathrm{m}$ using a ball mill instrument (clay fractions were obtained by wet sedimentation).

Purification of bentonite samples: Half the raw samples were purified in terms of quartz removal and the process was undertaken using the following steps: Firstly, the raw bentonite samples were mixed with distilled water and the temperature of the suspension was recorded $\left(22^{\circ} \mathrm{C}\right)$. The suspension was centrifuged at $700 \mathrm{rpm}$ for $3.50 \mathrm{~min}$, to obtain particles less than $2 \mu \mathrm{m}$. These particles were carefully separated into large bottles. This process was repeated four times for each sample, to guarantee obtaining samples in a pure form [32]. The suspension was collected, following evaporation of the water at $35^{\circ} \mathrm{C}$ on a hot plate. The samples were dried in an oven at $60^{\circ} \mathrm{C}$ and ground and sieved using a $63 \mu \mathrm{m}$ mesh and finally stored in polyethylene bottles.

Collection, preservation and pretreatment of olive mill wastewater samples: Approximately $500 \mathrm{~L}$ of fresh olive mill wastewater were collected during the 4th quarter of 2016, from an olive mill in Kofranjeh village at Jerash city, about $48 \mathrm{~km}$ north of the capital Amman. In this mill, olive oil is produced by the centrifugal method. The olive mill wastewater samples were collected in plastic containers $(20 \mathrm{~L})$, transported immediately to a laboratory at Jerash University and stored at approximately $10{ }^{\circ} \mathrm{C}$. As a pretreatment, aliquots of $1 \mathrm{~L}$ of olive mill wastewater were centrifuged at 10,000 rpm for $30 \mathrm{~min}$ and double simple filtration was undertaken, to obtain a clear and dark (brownish) solution.

Adsorbent characterization: The physical and chemical characteristics of both raw and purified bentonite were characterized by using several techniques, including Fourier transforms infrared spectrometer (FTIR), X-ray diffraction (XRD) and thermogravimetric analysis (TGA). The surface area and point of zero charge were also determined.

The functional groups that may affect the adsorption process were detected by FTIR studies using a Thermo Nicolet NEXUS 670 FT-IR Spectrophotometer. The crystalline structure of bentonite was determined by XRD analysis using Philips X pert pro, with $\mathrm{CuK}_{\alpha}$ radiations of wavelength $(\lambda=1.5406 \AA)$, generated at $30 \mathrm{Kv}$ to $30 \mathrm{~mA}$. The scan measurements were performed at $2 \theta$ range of $4-100^{\circ}$ with a scan speed of $2 \% \mathrm{~min}$ in the sampling pitch of $0.02^{\circ}$. Thermal properties of the bentonite were investigated by a NETZCH STA 409 PG/PC Thermal Analyzer in the temperature range $0-1000{ }^{\circ} \mathrm{C}$, with a heating rate of $20^{\circ} \mathrm{C} / \mathrm{min}$ in argon atmosphere.

Brunauer-Emmer-Teller (BET) surface area of raw bentonite and purified bentonite were determined from the corresponding nitrogen adsorption-desorption isotherms (at $77 \mathrm{~K}$ ) and a relative pressure $\left(\mathrm{P} / \mathrm{P}_{0}\right)$ of approximately 0.95 , using Gemini VII from micromeritics.

The $\mathrm{pH}$ point of zero charge (PZC) of raw bentonite and purified bentonite were carried out using a Zeta Meter 3.0 (Zeta Meter Inc.). Concentrations of total phenolic compounds content were determined using a UV-VIS spectrophotometer (Varian cary100). Shaking of samples was done using a Clifton Shaker equipped with a thermostat and $\mathrm{pH}$ was measured using a METROHM 605 pH-meter.

Analytical methods: Analytical grade reagents and chemicals with purity over $99 \%$ were used. For HMIS determination tests, $\mathrm{Zn}, \mathrm{Fe}$ and Mn a standard solution of each metal ion concentration was prepared in $\mathrm{NaClO}_{4}$ at $\mathrm{pH}=6$. The $\mathrm{pH}$ of these solutions was adjusted using $0.1 \mathrm{M} \mathrm{HCl}$ and $0.1 \mathrm{M} \mathrm{NaOH}$, to achieve the desired values. Concentrations of the metal ions were determined using a Varian Spectra AA-250 pulse atomic absorption spectrometer (AAS). To measure soluble sodium and potassium, concentrations were determined using a flame photometer (Corning 400).

A COD and multiparameter bench meter, PN HI83099-02, was used for the measurement of COD, alkalinity, total nitrate, total phosphate and total chlorine concentrations. DO, ORP, TDS, salt, conductivity and $\mathrm{pH}$ measurements were assessed with a Crison PL-700AL meter, provided with auto correction of temperature. Buffer standard solutions for EC (1413 and $12.88 \mathrm{mS} \mathrm{cm}^{-1}$ ) and $\mathrm{pH}(\mathrm{pH} \mathrm{4.01,7.00} \mathrm{and} \mathrm{9.21)} \mathrm{measurements,}$ respectively, were supplied as well by Crison.

The total phenolic compounds were evaluated by spectrophotometry using the Folin-Ciocalteu method. Briefly, a 2.5 $\mathrm{mL}$ portion of Folin-Ciocalteu reagent $0.2 \mathrm{~N}$ was mixed with $0.5 \mathrm{~mL}$ of the sample. The reaction was kept in the dark for 5 min. Then, $2 \mathrm{~mL}$ of a sodium carbonate solution $(75 \mathrm{~g} / \mathrm{L})$ was added to the mixture and the reaction was kept in the dark for $1 \mathrm{~h}$. The absorbance was measured at $765 \mathrm{~nm}$ in atomic absorption spectrometer. Gallic acid was used as a phenolic compound standard for the calibration curve $(330 \mathrm{mg} / \mathrm{L}$; y $=0.0598 \mathrm{x}-$ 0.0636 , where $\mathrm{x}$ and $\mathrm{y}$ represent the gallic acid concentration $(\mathrm{mg} / \mathrm{L})$ and absorbance at $765 \mathrm{~nm}$, respectively; $\left(\mathrm{R}^{2}=0.9977\right)$. Contents of the total phenolic compounds in olive mill wastewater were expressed as gallic acid equivalents in grams per liter (g GAE/L residue) [33]. 
Several parameters were tested to determine adsorption effectiveness. Batch experiments were carried out by mixing $10 \mathrm{~mL}$ of olive mill wastewater with different amounts of bentonite $(0.1,0.5,1.0 \mathrm{~g})$ at different temperatures $(298,303$, 313 and $323 \mathrm{~K}$ ). olive mill wastewater and bentonite clay were stirred in tubes continuously for $3 \mathrm{~h}$. Finally, all analytical methods were applied at least in triplicate.

Adsorption process: The samples of raw bentonite and purified bentonite were tested for the adsorption of HMIS from olive mill wastewater using a column technique. Adsorption processes were carried out in a column of $560 \mathrm{~mm}$ length and $12 \mathrm{~mm}$ diameter. $1.00 \mathrm{~g} \pm 0.0001 \mathrm{~g}$ of each adsorbent were packed in a column and $100 \mathrm{~mL}$ of olive mill wastewater was passed through the column. The flow rates were $0.25 \mathrm{~mL} / 180$ min and $0.25 \mathrm{~mL} / \mathrm{min}$ for both raw bentonite and purified bentonite, respectively. The effluent was collected as 10 separate samples, each having a volume of $10 \mathrm{~mL}$. Concentration of metal retained in the adsorbent phase $\left(\mathrm{q}, \mathrm{mg} \mathrm{g}^{-1}\right)$ was calculated from the following equation:

$$
\mathrm{q}=\frac{\left(\mathrm{C}_{\mathrm{i}}-\mathrm{C}_{\mathrm{e}}\right)}{\mathrm{m}} \times \mathrm{V}
$$

where $\mathrm{q}$ is the adsorbent phase concentration after equilibrium (mg metal ion/g adsorbent), $\mathrm{C}_{\mathrm{i}}$ and $\mathrm{C}_{\mathrm{e}}$ are the initial and final (equilibrium) concentrations of metal ion in solution $(\mathrm{mg} / \mathrm{L})$, $\mathrm{V}$ is the solution volume $(\mathrm{L})$ and $\mathrm{m}$ is the adsorbent mass $(\mathrm{g})$. $\%$ Removal of metal ion was calculated using the following equation:

$$
\operatorname{Removal}(\%)=\frac{\left(\mathrm{C}_{\mathrm{i}}-\mathrm{C}_{\mathrm{e}}\right)}{\mathrm{C}_{\mathrm{i}}} \times 100
$$

\section{RESULTS AND DISCUSSION}

Characterization of adsorbent: The FTIR spectra of raw bentonite and purified bentonite are illustrated in Fig. 1. The spectrum of raw bentonite before purification showed absorption bands at 3621.68 and $3695.46 \mathrm{~cm}^{-1}$ which correspond to the inner surface $\mathrm{OH}$ stretching vibrations. The band at 2361.41 $\mathrm{cm}^{-1}$ also corresponds to the $\mathrm{OH}$ stretching vibration. The presence of $1652.09 \mathrm{~cm}^{-1}$ indicates the $\mathrm{OH}$ bending vibration of water [34]. The $\mathrm{Si}-\mathrm{O}$ bending vibration was indicated by absorption bands at $1030.94 \mathrm{~cm}^{-1}$, while the $\mathrm{Si}-\mathrm{O}$ stretching vibrations were observed at 795.62 and $692.13 \mathrm{~cm}^{-1}$. The presence of Al-O-Si skeletal vibrations were revealed by the bands at 517.09 and $466.94 \mathrm{~cm}^{-1}$ [35].

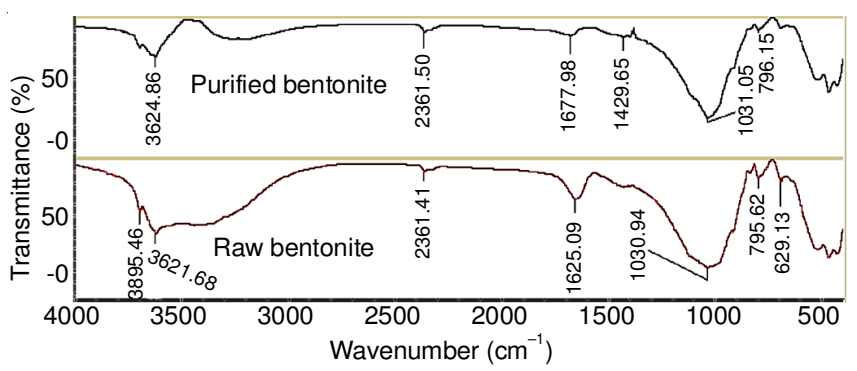

Fig. 1. FTIR spectra of raw bentonite and purified bentonite

Following the purification process of raw bentonite, there were shifts in the frequency of absorption from 3624.86 to
$3624.86 \mathrm{~cm}^{-1}, 2361.41$ to $2361.50 \mathrm{~cm}^{-1}, 795.62$ to $796.15 \mathrm{~cm}^{-1}$ and the disappearance of the band at $1652.09 \mathrm{~cm}^{-1}$, which indicated that the water molecules present in the interlayer region had been released and left behind a cavity or extra space in the skeleton of the bentonite structure. As a result, the adsorption capacity of HMIS and phenolic compounds were increased. The Si-O group was also involved in the absorption, as can be observed by their shifts in absorption frequency from 795.62 to $796.15 \mathrm{~cm}^{-1}$. In general, the shifts in these absorption bands confirm the purification process.

Jordanian bentonite is composed mainly of montmorillonite as the major constituent, while other components present, such as kaolinite, illite, feldspar, muscovite and quartz are impurities or accessory materials, as shown from the XRD analysis (Fig. 2). A similar composition has been reported by Mahasneh and Shakhatreh [36] on the characterization of Jordanian bentonite. Furthermore, an important decrease of minor components (impurities) was observed after purification and the intensities of montmorillonite peaks were increased. Since we had observed that montmorillonite possesses both Brønsted and Lewis acid sites, which are responsible for its adsorption capacity [37].

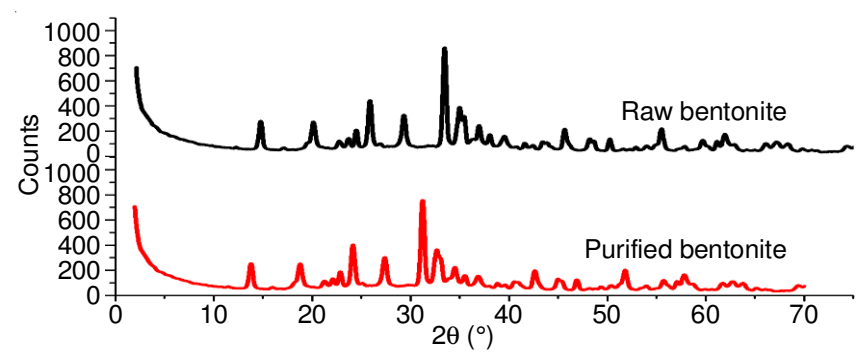

Fig. 2. XRD spectra of raw bentonite and purified bentonite

Thermogravimetric analysis (TGA) of raw bentonite and purified bentonite were also used to assess the thermal stability of the adsorbents. It can be seen from Fig. 3 that both adsorbents have shown high thermal stability, since only $10.13 \%$ of raw bentonite was decomposed until $1000{ }^{\circ} \mathrm{C}$. However, purified bentonite shows a higher thermal stability and the residue weight is only $9.42 \%$. The mass losses observed in the range, from room temperatures to $200{ }^{\circ} \mathrm{C}$, are related to the removal of adsorbed and interlayer water molecules. From 400 to $700{ }^{\circ} \mathrm{C}$, these mass losses are due to dehydration and dehydroxylation [38].

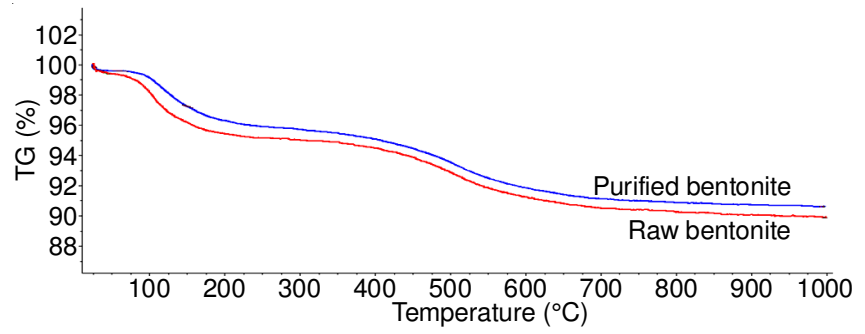

Fig. 3. TGA curve of raw bentonite and purified bentonite

The $\mathrm{pH}$ point of zero charge (PZC) can be defined as the $\mathrm{pH}$ at which there is a net zero charge on the surface of the adsorbent [39]. The functional groups on an adsorbent surface may acquire a negative or positive charge, depending on the 
$\mathrm{pH}$ of the solution. There exists a relationship between the point of zero charge and adsorption capacity of an adsorbent: cations adsorption will be favourable at $\mathrm{pH}$ values higher than the point of zero charge when the surface of the adsorbent is negatively charged, while anions adsorption will be favoured at $\mathrm{pH}$ values lower than the point of zero charge when the adsorbent surface is positive [40]. The point of zero charge of raw bentonite and purified bentonite is 3.2 and 3.0, respectively. Such behaviour can be explained by increasing the negative surface charges of the bentonite after purification. Furthermore, this behaviour implies that the adsorption process can take place in a wide range of $\mathrm{pH}$, even at low $\mathrm{pH}$ values (as low as $\mathrm{pH}$ 3.0). Both Jordanian raw bentonite and purified bentonite also recorded a BET surface area of 66.2 and $147.8 \mathrm{~m}^{2} \mathrm{~g}^{-1}$, respectively. The same results have been obtained for Nigerian bentonite; $69.34 \mathrm{~m}^{2} \mathrm{~g}^{-1}$ [41]. The surface area of raw bentonite is high and when purified it is even higher. In fact, the surface area increased with particle size reduction. This means that during purification the size of the particles becomes smaller, which is desirable for an effective adsorption. Jordanian bentonite was found to have a higher surface area than others, depending on its source, for example Brazilian and South African bentonite had surface areas of $34.1 \mathrm{~m}^{2} \mathrm{~g}^{-1}$ [42] and $37 \mathrm{~m}^{2} \mathrm{~g}^{-1}$ [43], respectively.

Analysis of olive mill wastewater: The results of the physico-chemical characteristics of the samples of untreated olive mill wastewater, which were treated by raw bentonite and purified bentonite, are summarized in Table-1. As shown, the olive mill wastewater had a high capacity value to induce a heavy pollution of the environment. Also, it should be pointed out that the treated olive mill wastewater, using either raw bentonite or purified bentonite, enhanced its properties. Moreover, the treatment using purified bentonite gave a better output. Potassium and sodium ions were reduced by $50 \%$. Reduction of the phosphorus and nitrogen content is in a good limit range and consistent with the 2004 Urban Wastewater Treatment (Amendment) Regulations, S.I. No. 440. The most important part is that the total phenolic content of olive mill wastewater was enriched in phenolic compounds and the percentage removal exceeded $50 \%$ of the content. The colour of the aqueous solution of olive mill wastewater after treatment became lighter, suggesting that the organic substances responsible for the dark colour remained. However, the olive mill wastewater was further examined for COD, DO and ORP and it was found that the treatment had reduced all these parameters by more than $50 \%$.

Adsorption studies for HMIS from olive mill wastewater using raw bentonite and purified bentonite: The adsorption of metal ions by clay using a column technique for $\mathrm{Zn}$ (II), $\mathrm{Fe}(\mathrm{II})$ and $\mathrm{Mn}$ (II) were studied.

Heavy metals are highly toxic and they act as non-biodegradable pollutants when they accumulate in the ecosystem. The emission of heavy metals from olive mill wastewater into the environment will pollute surface and underground water sources and this may lead to soil pollution. When agricultural soils are polluted, these metals are taken up by plants and consequently they accumulate in their tissues [59]. Animals feeding on such contaminated plants and drinking from polluted waters, including marine life that breeds in heavy metal polluted waters, accumulate such metals in their tissues and milk, if lactating [60]. This situation has resulted in the establishment of olive mill wastewater regulations, in order to minimize human and environmental exposure to hazardous pollutants.

Recently, the adsorption process has gained interest as a more promising method for the long term, as it is seen to be a more effective and economic process [61].

Our experiments for the removal of HMIS were run out at $\mathrm{pH} 6$, for both adsorbents, which was higher than the point of zero charge value at which ion exchange mechanism would take place. More active sites resulted in an adsorbent surface and as a result, there was an increase in adsorption capacity. Higher $\mathrm{pH}$ values greater than 7.0 are usually avoided in most adsorption studies, due to the possibility of metal precipitation [62].

TABLE-1

AVERAGE PHYSICO-CHEMICAL CHARACTERISTICS OF UNTREATED AND TREATED OLIVE MILL WASTEWATER SAMPLES

\begin{tabular}{|c|c|c|c|c|c|c|c|}
\hline Parameters & $\begin{array}{c}\text { Untreated } \\
\text { olive mill } \\
\text { wastewater }\end{array}$ & $\begin{array}{l}\text { Literature } \\
\text { ranges values }\end{array}$ & $\begin{array}{c}\text { Treated } \\
\text { olive mill } \\
\text { wastewater } \\
\text { with raw } \\
\text { bentonite }\end{array}$ & $\begin{array}{c}\text { Treated } \\
\text { olive mill } \\
\text { wastewater } \\
\text { with purified } \\
\text { bentonite }\end{array}$ & $\begin{array}{c}\text { Removal } \\
\text { using raw } \\
\text { bentonite }(\%)\end{array}$ & $\begin{array}{c}\text { Removal } \\
\text { using purified } \\
\text { bentonite }(\%)\end{array}$ & Ref. \\
\hline $\mathrm{pH}$ & 4.63 & $4.9-6.50$ & 5.74 & 5.75 & - & - & [44] \\
\hline Conductivity $(\mathrm{ms} / \mathrm{cm})$ & 19.89 & $13-50$ & 19.4 & 18.9 & - & - & {$[45,46]$} \\
\hline Sodium $\left(\mathrm{mg} \mathrm{L}^{-1}\right)$ & 297.9 & $200-570$ & 186.4 & 149.2 & 37.4 & 49.9 & {$[47,48]$} \\
\hline Potassium $\left(\mathrm{mg} \mathrm{L}^{-1}\right)$ & 6366.3 & $639-10800$ & 4075.1 & 3103.7 & 35.9 & 51.3 & {$[49,50]$} \\
\hline Total phenolic content (g GAE/L) & 1.34 & $0.26-10.7$ & 0.85 & 0.66 & 36.6 & 50.8 & {$[49,51]$} \\
\hline Alkalinity $\left(\mathrm{mg} \mathrm{L}^{-1}\right)$ & 2000 & $3150-9070$ & 1500 & 1470 & 25.0 & 26.5 & {$[52]$} \\
\hline Total chlorine $\left(\mathrm{mg} \mathrm{L}^{-1}\right)$ & 20 & $33.3-142.7$ & 15 & 11 & 25.0 & 45.0 & [53] \\
\hline Phosphate (mg L $\left.{ }^{-1}\right)$ & 4120 & $31.8-1820$ & 460 & 350 & 88.8 & 91.5 & [54] \\
\hline Nitrate $\left(\mathrm{mg} \mathrm{L}^{-1}\right)$ & 360 & $350-390$ & 230 & 40 & 36.1 & 88.9 & [55] \\
\hline $\mathrm{COD}\left(\mathrm{mg} \mathrm{L}^{-1}\right)$ & 12000 & $1900-220000$ & 7030 & 4250 & 41.4 & 64.6 & {$[56,57]$} \\
\hline $\mathrm{DO}\left(\mathrm{mg} \mathrm{L}^{-1}\right)$ & 600 & n.d. & 297 & 292 & 50.5 & 51.3 & - \\
\hline $\operatorname{TDS}\left(\mathrm{mg} \mathrm{L}^{-1}\right)$ & 34700 & $5900-103200$ & 13140 & 12030 & 62.1 & 65.3 & {$[56,58]$} \\
\hline $\mathrm{ORP}(\mathrm{mv})$ & 259800 & n.d. & 73300 & 72300 & 71.8 & 72.2 & - \\
\hline Salt $\left(\mathrm{mg} \mathrm{L}^{-1}\right)$ & 26700 & $11900-32000$ & 9930 & 9810 & 62.8 & 63.3 & {$[52]$} \\
\hline
\end{tabular}

n.d.: not determined; ORP: Oxidation reduction potential; Every measurement was repeated three times, to ensure the accuracy and reproducibility of the results and then an average was taken. 
As can be seen in Table-2, olive mill wastewater produced in Jerash city contained a massive concentration of 2025, 1347 and $1242 \mathrm{ppm}$ of $\mathrm{Fe}, \mathrm{Zn}$ and $\mathrm{Mn}$ ions, respectively. Both raw bentonite and purified bentonite have been shown to be extremely effective in the adsorption process. The metal adsorption capacity (q) values are very high. In addition, results have shown in Figs. 4 and 5 that the percentage uptake for all metal ions is excellent. Raw bentonite and purified bentonite have been studied as potential low-cost adsorbents for the treatment of olive mill wastewater afflicted with heavy metal ions and these adsorbents are highly recommended to carry out this process.

TABLE-2

ADSORPTION CAPACITY (q, $\mathrm{mg} \mathrm{g}^{-1}$ ) OF HMIS USING RAW BENTONITE AND PURIFIED BENTONITE AT $298 \mathrm{~K}$

\begin{tabular}{cccc}
\hline $\begin{array}{c}\text { Heavy } \\
\text { metal }\end{array}$ & $\begin{array}{c}\text { Initial metal ion } \\
\text { concentration } \\
(\mathrm{ppm})\end{array}$ & $\begin{array}{c}\text { Raw bentonite } \\
\left(\mathrm{mg} \mathrm{g}^{-1}\right)\end{array}$ & $\begin{array}{c}\text { Purified bentonite } \\
\left(\mathrm{mg} \mathrm{g}^{-1}\right)\end{array}$ \\
\hline $\mathrm{Zn}$ & 1341 & 133.97 & 134.08 \\
$\mathrm{Fe}$ & 2025 & 204.40 & 202.17 \\
$\mathrm{Mn}$ & 1242 & 124.14 & 124.19 \\
\hline
\end{tabular}

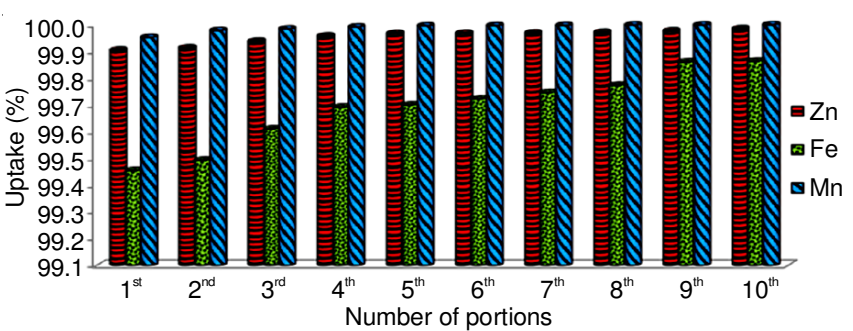

Fig. 4. Percentage uptake of metal ions by raw bentonite using column technique

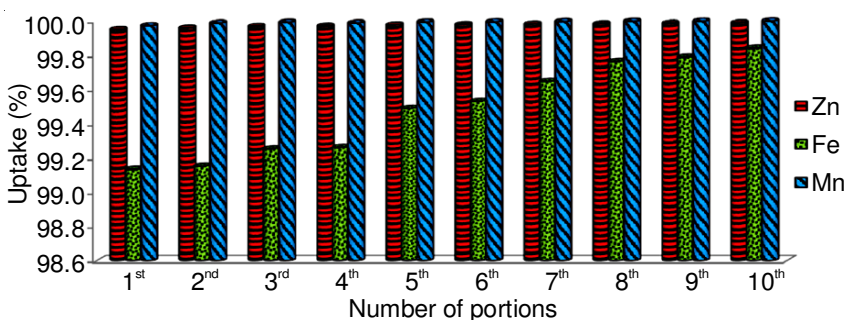

Fig. 5. Percentage uptake of metal ions by purified bentonite using column technique

Total phenolic compounds content: Purified bentonite was found to be a more effective adsorbent than raw bentonite in a single step batch system of $3 \mathrm{~h}$, where 133.95 and $18.53 \mathrm{mg}$ of phenol content was removed with $0.1 \mathrm{~g}$ of purified bentonite and raw bentonite, respectively. On the other hand, the q value $\left(\mathrm{mg} \mathrm{g}^{-1}\right)$ of phenolic compounds removal was decreased as the adsorbent dose was increased. A constant volume of olive mill wastewater and a constant initial concentration of phenol content were used (Table-3), which can be explained because of phenolic compounds adsorption. However, this situation will lead to the unsaturation of adsorption sites through the adsorption process. It is therefore clear that the equilibrium adsorption capacity of bentonite clay is a function of its mass [63].

The percentage uptake of values, directly proportional to the adsorbent dose, showed that purified bentonite was more
TABLE-3

EFFECT OF VARYING BENTONITE DOSE ON

THE ADSORPTION OF PHENOLIC COMPOUNDS; OPERATION CONDITIONS: $298 \mathrm{~K}, 10 \mathrm{~mL}$ OF OLIVE MILL WASTEWATER AND THE CONTACT TIME $=3 \mathrm{~h}$

\begin{tabular}{ccc|cc}
\hline \multirow{2}{*}{$\begin{array}{c}\text { Mass of } \\
\text { adsorbent } \\
(\mathrm{g})\end{array}$} & \multicolumn{2}{c|}{ Raw bentonite } & \multicolumn{2}{c}{ Purified bentonite } \\
\cline { 2 - 5 } & $\mathrm{q}\left(\mathrm{mg} \mathrm{g}^{-1}\right)$ & Uptake (\%) & $\mathrm{q}\left(\mathrm{mg} \mathrm{g}^{-1}\right)$ & Uptake (\%) \\
\hline 0.1 & 18.53 & 13.8 & 133.95 & 17.2 \\
0.5 & 5.28 & 19.7 & 26.79 & 29.4 \\
1.0 & 4.89 & 36.5 & 13.39 & 40.7 \\
\hline
\end{tabular}

active than raw bentonite and interestingly these results would have important implications in the cost-effectiveness (at 298 $\mathrm{K}$, energy save) of the final purification of olive mill wastewater by bentonite. Moreover, the effective recovery of phenolic compounds may provide value-added natural ingredients in food preservative. The most interesting one appears to be hydroxyl tyrosol, a compound of high added value, due to its antioxidant and potentially beneficial (to human health) properties. It could be also used in the cosmetics industry regarding antiaging preparations $[64,65]$.

Total phenolic compounds adsorption efficiencies were found to be considerably affected by the operating temperature, which increased with temperature (Fig. 6). This is due to the endothermic adsorption of phenolic compounds, which cause the equilibrium constants for this reaction to increase with temperature and thus reaction products are favored at high temperatures.

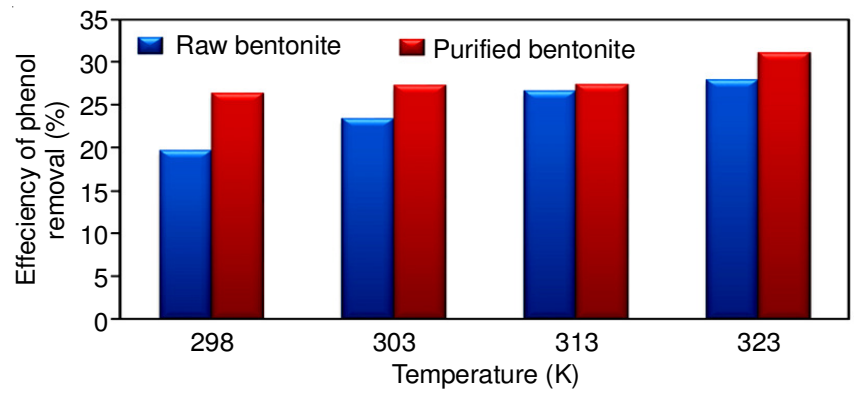

Fig. 6. Effect of solution temperature on the percentage removal of phenolic compounds; Operation conditions: $10 \mathrm{~mL}$ of olive mill wastewater, mass of bentonite dose $=0.5 \mathrm{~g}$ and contact time $=3 \mathrm{~h}$

It is worth highlighting that phenol molecule presents a $\mathrm{pKa}$ value of 9.95, which implies that phenol is neutral in the $\mathrm{pH}$ range below 9.95. Thus, in current working conditions, phenol is in its neutral form and ion exchange is probably not taking place. However, the working $\mathrm{pH}$ is 6 , greater than point of zero charge, which means that we have an anionic bentonite surface and the responsible mechanism of this retention could be adsorption/partition or size exclusion [66]. In addition, bentonite has a large surface area and it has considerable numbers of pores, where there is a good possibility for phenolic compounds to be trapped and adsorbed.

\section{Conclusion}

Olive mill wastewater are produced in the Jordan and Mediterranean regions in huge amounts and this results in heavily polluted waste water that causes negative environmental impacts. Untreated olive mill wastewater is characterized by a 
high content of phenolic compounds, potassium, phosphate, nitrate and salt. Bentonite has a great potential for the removal of HMIS and other organic pollutants from olive mill wastewater. Moreover, the purification of raw bentonite through a simple and low cost method enhances its capacity and other characteristics. Both raw bentonite and raw bentonite showed a high capacity to adsorb heavy metal ions, with the percentage uptakes exceeding $99 \%$ for $\mathrm{Zn}, \mathrm{Fe}$ and Mn. While the q value of phenolic compounds removal using purified bentonite was better than raw bentonite.

This treatment approach is environmentally friendly and the treatment process can take place at the location where the water is being produced. The obtained final treated olive mill wastewater was clear, with a low concentration of organics content and salts, which may be disposed in landfills or used for irrigation, without environmental risks.

\section{ACKNOWLEDGEMENTS}

The author is grateful for the Support to Research and Technological Development \& Innovation Initiatives and Strategies in Jordan (SRTD II), the European Union Funded Project, Budget line BGUE-2011-19.080101-CI-DEVCO, Reference: SRTD/2014/GRT/AR/2321, for having funded the project, in addition to Jerash University.

\section{REFERENCES}

1. M. Faramarzi, K.C. Abbaspour, W.L. (Vic) Adamowicz, W. Lu, J. Fennell, A.J.B. Zehnder and G.G. Goss, J. Hydrol.: Regional Stud., 9, 48 (2017); https://doi.org/10.1016/j.ejrh.2016.11.003.

2. A. Al-Khatib, F. Aqra, M. Al-Jabari, N. Yaghi, S. Basheer, I. Sabbah, B. Al-Hayek and M. Mosa, Bulg. J. Agric. Sci., 15, 544 (2009).

3. L. Chaari and N. Elloumi, Int. J. Interdiscipl. Multidiscipl. Stud., 2, 175 (2014).

4. D. Bouknana, B. Hammouti, R. Salghi, S. Jodeh, A. Zarrouk, I. Warad, A. Aouniti and M. Sbaa, J. Mater. Environ. Sci., 5, 1039 (2014).

5. K. Komnitsas and D. Zaharaki, Resour. Conserv. Recycling, 69, 82 (2012); https://doi.org/10.1016/j.resconrec.2012.09.009.

6. A. Aly, Y. Hasan and A. Al-Farraj, J. Environ. Manage., 145, 341 (2014); https://doi.org/10.1016/j.jenvman.2014.07.012.

7. A. Dhouib, F. Aloui, N. Hamad and S. Sayadi, Process Biochem., 41, 159 (2006);

https://doi.org/10.1016/j.procbio.2005.06.008.

8. M. Panizza and G. Cerisola, Water Res., 40, 1179 (2006); https://doi.org/10.1016/j.watres.2006.01.020.

9. F. Hanafi, O. Assobhei and M. Mountadar, J. Hazard. Mater., 174, 807 (2010); https://doi.org/10.1016/j.jhazmat.2009.09.124.

10. A. Roig, M. Cayuela and M. Sanchez-Monedero, Waste Manage., 26, 960 (2006); https://doi.org/10.1016/j.wasman.2005.07.024.

11. C. Anastasiou, P. Christou, A. Michael, D. Nicolaides and T. Lambrou, Environ. Res. J., 5, 49 (2011).

12. C. McNamara, C. Anastasiou, V. O'Flaherty and R. Mitchell, Int. Biodeter. Biodegrad., 61, 127 (2008); https://doi.org/10.1016/j.ibiod.2007.11.003.

13. E. Tsagaraki and H. Lazarides, Food Bioprocess Technol., 5, 584 (2012); https://doi.org/10.1007/s11947-010-0326-4.

14. D. Zagklis, E. Arvaniti, C. Papadakis and C. Paraskeva, J. Chem. Technol. Biotechnol., 88, 742 (2013); https://doi.org/10.1002/jctb.4036.

15. B. Zenjari and A. Nejmeddine, Agronomie, 21, 749 (2001); https://doi.org/10.1051/agro:2001163.

16. Y.S. Ho and G. McKay, Trans IChemE Part B, 77, 165 (1999).

17. S. Schiewer and S.B. Patil, J. Hazard. Mater., 157, 8 (2008); https://doi.org/10.1016/j.jhazmat.2007.12.076.
18. M. Amer, F. Khalili and A. Awwad, J. Environ. Chem. Ecotoxicol., 2, 1 (2010).

19. K.B. Payne and T.M. Abdel-Fattah, J. Environ. Sci. Health Part A Tox. Hazard. Subst. Environ. Eng., 39, 2275 (2004); https://doi.org/10.1081/ESE-200026265.

20. Y. Dong, D. Wu, X. Chen and Y. Lin, J. Colloid Interface Sci., 348, 585 (2010); https://doi.org/10.1016/j.jcis.2010.04.074.

21. R.A. Donat, A. Akdogan, E. Erdem and H. Cetisli, J. Colloid Interface Sci., 286, 43 (2005); https://doi.org/10.1016/j.jcis.2005.01.045.

22. M. Malusis, J. Maneval, E.J. Barben, C.D. Shackelford and E. Daniels, J. Contam. Hydrol., 116, 58 (2010); https://doi.org/10.1016/j.jconhyd.2010.06.001.

23. K. Bhattacharyya and S. Gupta, Sep. Purif. Technol., 50, 388 (2006); https://doi.org/10.1016/j.seppur.2005.12.014.

24. T.S. Polubesova, S. Eldad and B. Chefetz, Environ. Sci. Technol., 44, 4203 (2010); https://doi.org/10.1021/es1007593.

25. F. Coppin, G. Berger, A. Bauer, S. Castet and M. Loubet, Chem. Geol., 182, 57 (2002); https://doi.org/10.1016/S0009-2541(01)00283-2.

26. M.R. Lawrence, R.K. Kukkadapu and S.A. Boyd, Appl. Clay Sci., 13, 13 (1998); https://doi.org/10.1016/S0169-1317(98)00009-X.

27. M. Karnib, A. Kabbani, H. Holail and Z. Olama, Energy Procedia, 50, 113 (2014); https://doi.org/10.1016/j.egypro.2014.06.014.

28. F. Caturla, J.M. Martín-Martínez, M. Molina-Sabio, F. RodriguezReinoso and R. Torregrosa, J. Colloid Interface Sci., 124, 528 (1988); https://doi.org/10.1016/0021-9797(88)90189-0.

29. S. Al-Asheh, F. Banat and L. Abu-Aitah, Sep. Purif. Technol., 33, 1 (2003); https://doi.org/10.1016/S1383-5866(02)00180-6.

30. A. Atia, F.M. Farag and A. Youssef, Colloids Surf. A, 278, 74 (2006); https://doi.org/10.1016/j.colsurfa.2005.11.091.

31. G. Thanos, A. Sotiropoulos, S. Malamis, E. Katsou, E.A. Pavlatou and K.J. Haralambous, Desalination Water Treat., 57, 27869 (2016); https://doi.org/10.1080/19443994.2016.1186395.

32. M.B. Salman, B. El-Eswed and F. Khalili, Appl. Clay Sci., 38, 51 (2007); https://doi.org/10.1016/j.clay.2007.02.011.

33. I. Leouifoudi, A. Zyad, A. Amechrouq, M.A. Oukerrou, H.A. Mouse and M. Mbarki, LWT-Food Sci. Technol., 34, 249 (2014); https://doi.org/10.1590/fst.2014.0051

34. A.M. Motawie, M.M. Madany, A.Z. El-Dakrory, H.M. Osman, E.A. Ismail, M.M. Badr, D.A. El-Komy and D.E. Abulyazied, Egyptian J. Petroleum, 23, 331 (2014); https://doi.org/10.1016/j.ejpe.2014.08.009.

35. C. Fernandes, C. Catrinescu, P. Castilho, P.A. Russo, M.R. Carrott and C. Breen, Appl. Catal. A Gen., 318, 108 (2007); https://doi.org/10.1016/j.apcata.2006.10.048.

36. S.K. Saleh and M.A. Mahasneh, J. Miner. Mater. Charact. Eng., 3, 477 (2015); https://doi.org/10.4236/jmmce.2015.36050.

37. F. Gonzalez, C. Pesquera, C. Blanco, I. Benito and S. Mendioroz, Inorg. Chem., 31, 727 (1992); https://doi.org/10.1021/ic00031a007.

38. M. Yurdakoc, M. Akçay, Y. Tonbul, F. Ok and K. Yurdakoc, Micropor. Mesopor. Mater, 111, 211 (2008); https://doi.org/10.1016/j.micromeso.2007.07.032.

39. E. Cristiano, Y. Hu, M. Siegfried, D. Kaplan and H. Nitsche, Clays Clay Miner., 59, 107 (2011); https://doi.org/10.1346/CCMN.2011.0590201.

40. M. Nomanbhay and K. Palanisamy, Electron. J. Biotechnol., 8, 43 (2005).

41. G.K. Akpomie and F. Dawodu, Beni-Suef Univ. J. Basic Appl. Sci., 4, 1 (2015); https://doi.org/10.1016/j.bjbas.2015.02.002.

42. D. Guerra, I. Mello, R. Resende and R. Silva, Water Resour. Ind., 4, 32 (2013); https://doi.org/10.1016/j.wri.2013.11.001.

43. M. Vhahangwele and G. Mugera, J. Environ. Chem. Eng., 3, 2416 (2015); https://doi.org/10.1016/j.jece.2015.08.016.

44. P. Galiatsatou, M. Metaxas, D. Arapoglou and V. Kasselouri-Rigopoulou, Waste Manage., 22, 803 (2002); https://doi.org/10.1016/S0956-053X(02)00055-7. 
45. A. Sassi, A. Boularbah, A. Jaouad, G. Walker and A. Boussaid, Process Biochem., 41, 74 (2006); https://doi.org/10.1016/j.procbio.2005.03.074.

46. M. Di Serio, B. Lanza, M. Mucciarella, F. Russi, E. Iannucci, P. Marfisi and A. Madeo, Int. Biodeter. Biodegrad., 62, 403 (2008); https://doi.org/10.1016/j.ibiod.2008.03.006

47. C. Piperidou, C. Chaidou, D. Stalikas, K. Soulti, G. Pilidis and C. Balis, J. Agric. Food Chem., 48, 1941 (2000); https://doi.org/10.1021/jf991060v.

48. E.Eroglu, I. Eroglu, U. Gündüz and M. Yücel, Bioresour. Technol., 99 , 6799 (2008); https://doi.org/10.1016/i.biortech.2008.01.076

49. F. Hanafi, N. Sadif, O. Assobhei and M. Mountadar, J. Water Sci., 22 473 (2009); https://doi.org/10.7202/038326ar.

50. E. Moreno, J. Pérez, A. Ramos-Cormenzana and J. Martínez, Microbios, 51, 169 (1987)

51. A.G. Vlyssides, M. Loizides and P. Karlis, J. Cleaner Prod., 12, 603 (2004); https://doi.org/10.1016/S0959-6526(03)00078-7.

52. M. Mouncif, S. Tamoh, M. Faid and A. Achkari-Begdouri, Grasas y Aceites, 44, 335 (1993); https://doi.org/10.3989/gya.1993.v44.i6.1059.

53. D. Bouknana, B. Hammouti, R. Salghi, S. Jodeh, A. Zarrouk, I. Warad, A. Aouniti, M. Sbaa, J. Mater. Environ. Sci., 5, 1039 (2014).

54. A. Aly, Y. Hasan and A. Al-Farraj, J. Environ. Manage., 145, 341 (2014); https://doi.org/10.1016/j.jenvman.2014.07.012.
55. M. Panizza and G. Cerisola, Water Res., 40, 1179 (2006); https://doi.org/10.1016/j.watres.2006.01.020.

56. J. Alba, New Technologies for Obtaining Olive Oil: Professional Fruit Growing (Supplement), vol. 62, pp. 85-95 (1994).

57. P. Passarinho, Ph.D. Thesis, Olive Mill Wastewater Detoxification. Instituto Superior Técnico, Universidade Técnica de Lisboa, Portugal (2002).

58. M. Hamdi, Environ. Technol., 14, 495 (1993); https://doi.org/10.1080/09593339309385318.

59. J. Duruibe, M. Ogwuegbu and J. Egwurugwu, Int. J. Phys. Sci., 2, 112 (2007).

60. R. Verma and P. Dwivedi, Recent Res. Sci. Technol., 5, 98 (2013).

61. H. Khatoon and J. Rai, Octa J. Environ. Res., 4, 208 (2016).

62. K. Akpomie, F. Dawodu and K. Adebowale, Alexandria Eng. J., 54, 757 (2015); https://doi.org/10.1016/j.aej.2015.03.025.

63. P. Dhorabe, D. Lataye and R. Ingole, Water Sci. Technol., 73, 955 (2016); https://doi.org/10.2166/wst.2015.575.

64. R. Ghanbari, F. Anwar, K. Alkharfy, A. Gilani and N. Saari, Int. J. Mol. Sci., 13, 3291 (2012); https://doi.org/10.3390/ijms13033291.

65. N. Allouche, I. Fki and S. Sayadi, J. Agric. Food Chem., 52, 267 (2004); https://doi.org/10.1021/jf034944u.

66. M. Víctor-Ortega, J. Ochando-Pulido, G. Hodaifa and A. MartinezFerez, Chem. Eng. Process., 85, 241 (2014); https://doi.org/10.1016/j.cep.2014.10.002. 